\title{
A REVIEW TO THE GENESIS, EVOLUTION AND CLASSIFICATION OF THE SOILS FORMED ON LIMESTONES AND DOLOMITES IN THE REPUBLIC OF MACEDONIA\#
}

\author{
Tatjana Mitkova*, Mile Markoski \\ Faculty of Agriculture Sciences and Food, Ss. Cyril and Methodius University, \\ Skopje, Republic of Macedonia \\ *e-mail: tmitkova@fznh.ukim.edu.mk
}

\begin{abstract}
The soils formed on limestones and dolomites in different locations in the Republic of Macedonia have been examined. These soils differ in their genesis, evolution and properties from soils formed on other substrates and have a number of specificities, whereby all their properties largely depend on the parent material. They occupy much of the soil cover of the Republic of Macedonia. The field examinations were carried out according to the generally accepted method in our country $[1,2]$. Most of them are under high mountainous pastures, some plots are under meadows and fields. They have great importance for the faster development of some industries in the country, forestry, tourism, as well as the agricultural development in the hilly and mountainous underdeveloped areas in our country.
\end{abstract}

Key words: soils formed on limestones and dolomites; genesis; evolution; classification

\section{INTRODUCTION}

The soils formed on limestones and dolomites occupy a large part of the soil cover of the Republic of Macedonia. Based on the pedological (soil) map of the Republic of Macedonia in scale 1:200.000 [3], these soils occupy around $12.45 \%$ of the total area of the Republic of Macedonia or 2.571.300ha. In this area, Calcomelanosols /WRB-Rendzic Leptosol [4], covers around 220.000ha or $8.55 \%$, Calcocambisols /WRB-Chromic Leptic Luvisol on hard limestones [4], covers around 100.000 ha or $3.88 \%$, but Terra Rossa /WRB-Rhodic Leptic Luvisol on hard limestones [4], rarely form continuous soil cover. These can be found on really small areas of karst relief, they have a concave shape and are characterized with mosaic and fragmented appearance, and cover around 260 ha or $1.00 \%$ of the total area [5].

The soils formed on limestones and dolomites differ in their genesis, evolution and properties from soils formed on other substrates and have a number of specificities. All their properties (physical, physi- cal-mechanical, chemical and biological) greatly depend on the parent material.

Calcomelanosols, and especially Terra Rossa and Brown soil on hard limestones and dolomites (Calcocambisols), are some of the insufficiently studied soil types in our country.

The motive for this research arose from the fact that they occupy much of the soil cover of the Republic of Macedonia and have great importance for the faster development of some industries in the country, forestry, tourism, as well as the agricultural development in the hilly and mountainous underdeveloped areas. The preservation of these soils in the Republic of Macedonia is especially important due to the higher extent of erosion, forest cutting, fires, excessive grazing, which made these researches even more significant.

In addition, the cartographic units with Terra Rossa areas were not distinguished on the pedological (soil) map of the Republic of Macedonia until these studies took place because did not exactly know their total area. 


\section{MATERIAL AND METHODS}

The field examinations of soils formed on limestones and dolomites were carried out on various locations on the territory of the Republic of Macedonia (Figures 1 and 2). Following the field recognition, a total of 52 basic pedological profiles out which, 34 were calcomelanosols, 13 calcocambi- sols and 5 profiles of terra rossa were excavated (Figure 3, 4 and 5) were collected regarding the soil genesis conditions (parent material, relief, climate, vegetation and human factor). The field examinations were carried out according to the generally accepted method in our country $[1,2]$. Detail facts and data about soil properties and methods were presented in [6].

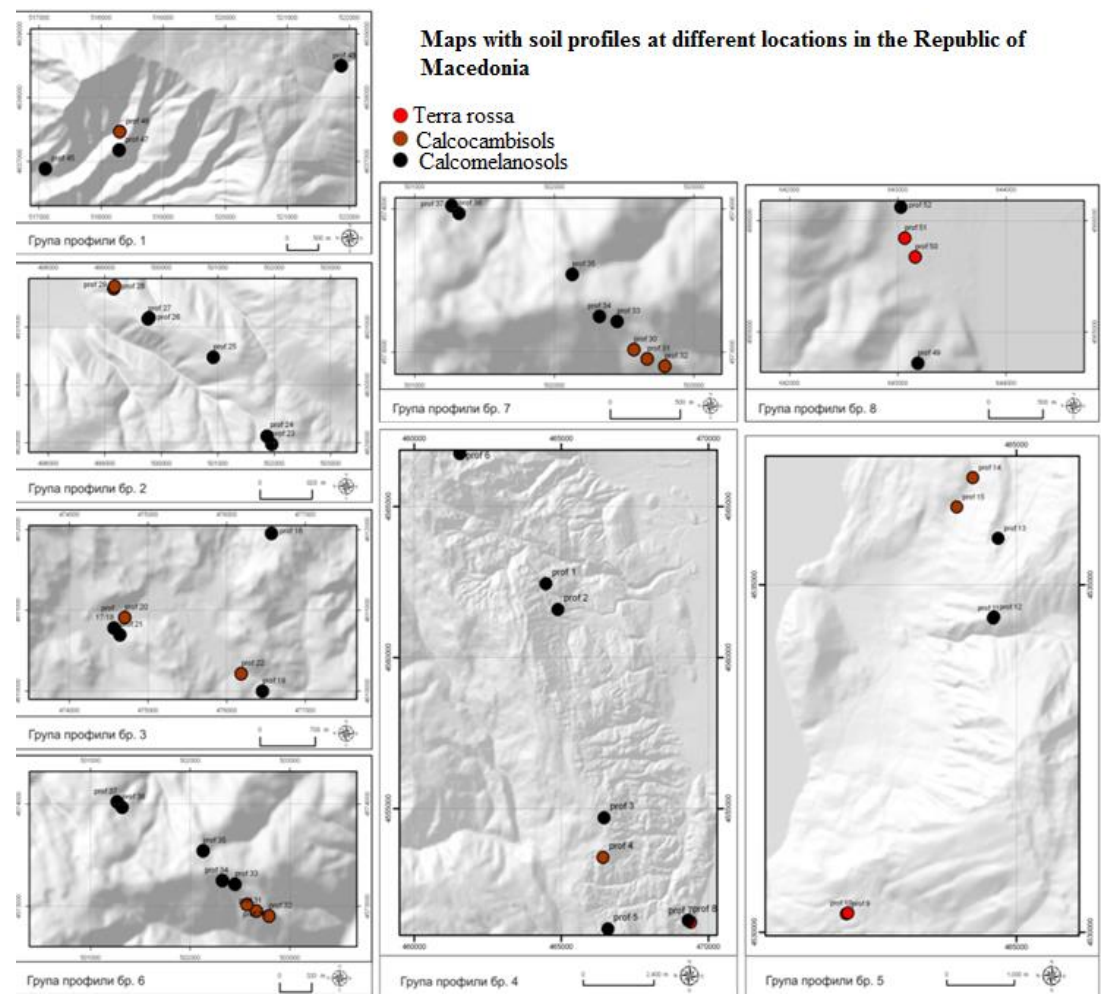

Figure 1. Map with soil profile at different locations in the Republic of Macedonia

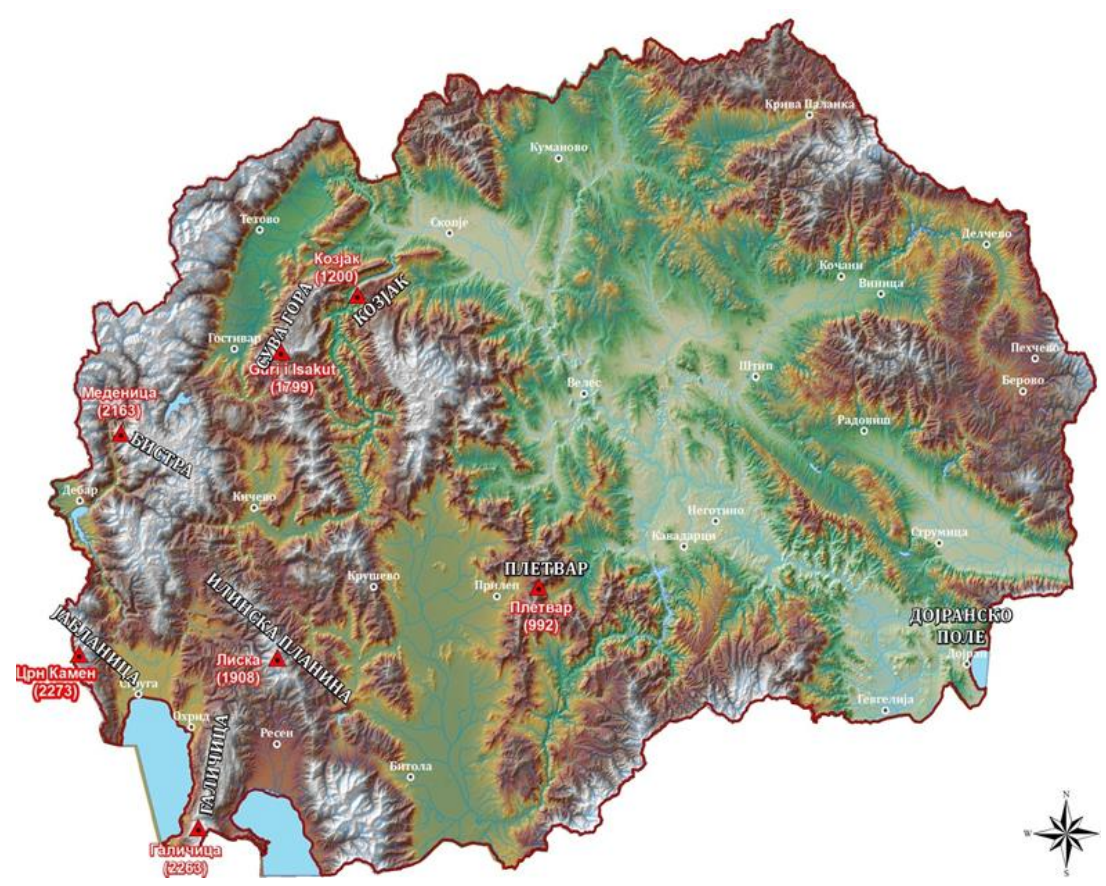

Figures 2. Map with the altitude of the soil profile at different locations in the Republic of Macedonia 


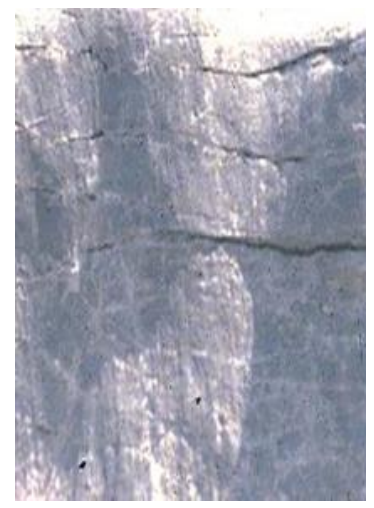

$\mathrm{R}$

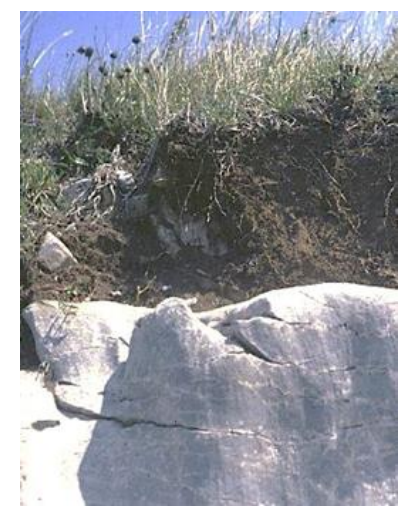

a) subtype organogenic Amo-R

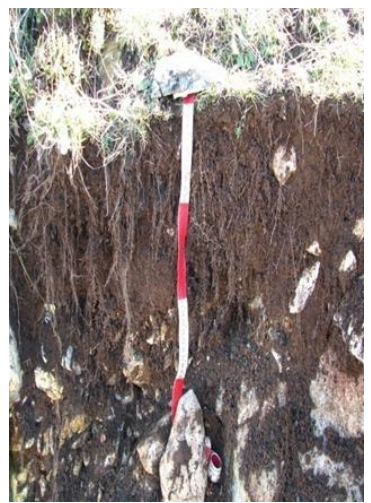

b) subtype organomineral Amo- $R$

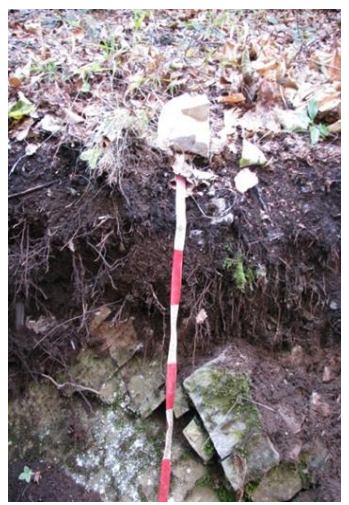

c) subtype brownised A-(B)rz-R

Figure 3. Calcomelanosols

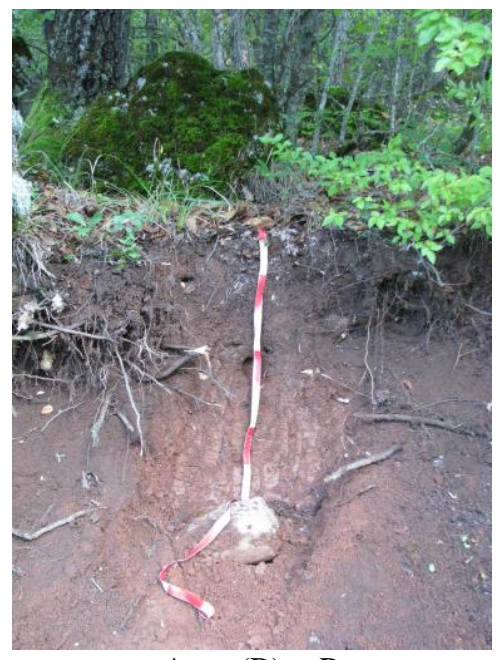

Amo-(B)rz-R

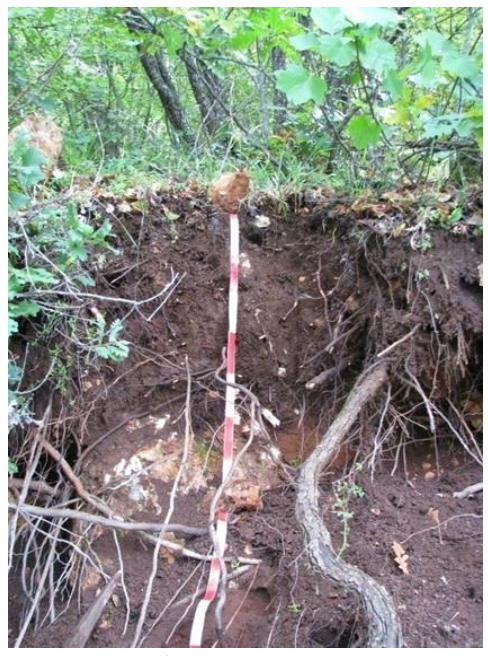

Amo-(B)rz-R

Figure 4. Calcocambisols

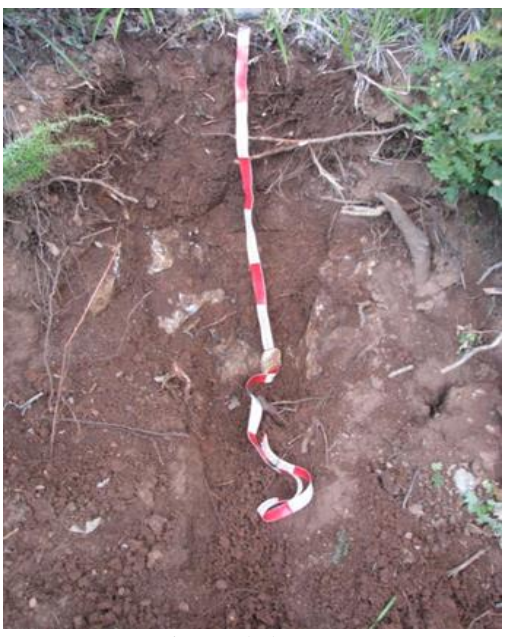

Amo-(B)rz-R

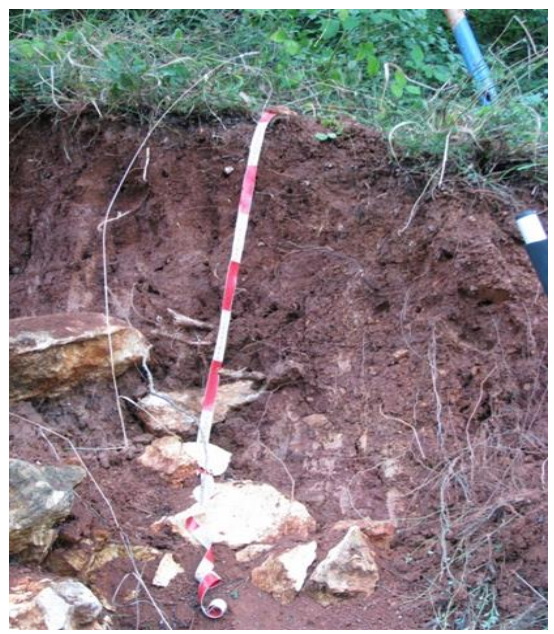

Amo-(B)rz-R

Figure 5. Terra Rossa 
RESULTS AND DISCUSSION

\section{Geneza of the soils formed on limestones and dolomites}

Calcomelanosols in their first stadium of development, appear in all climate-vegetation zones in our country, thus it can be said that the substrate is the main soil forming factor. However, the opinions on the soil forming factors in the literature differ. According to some authors cf. in [7], terra rossa are lithogenic soils, as they are formed in a similar way as calcomelanosols, on pure compact limestones and dolomites, and according to other authors, these are zonal soils as they appear only in the Mediterranean and modified Mediterranean climate. Third authors cf. in [7] combine these opinions and claim that these are lithogenic-climatogenic soils since the substrate is dominant soil forming factor for their formation, and the climate factor contributes for their preservation or evolution. Similar to calcomelanosols, calcocambisols can be treated for lithogenic soils, however, according to [7], these soils are not formed in some climate-vegetation zones of limestone - dolomite mountain ranges in our country, which speaks for the strong influence of other soil forming factors and points out to their zonal character.

Markoski, et. al., [6, 6a] described each of the soil forming factors and their significance in the formation of soils on limestones and dolomites in the Republic of Macedonia.

The following three processes take place in calcomelanosols: 1. Dissolving of $\mathrm{CaCO}_{3}$ and $\mathrm{MgCO}_{3}$ from limestone and dolomite and their leaching; 2. Accumulation of organic matter and formation of the humus horizon and 3. Formation of (B)rz horizon (only in brownised calcomelanosols). The third process is the most specific in the genesis of calcocambisols [7].

The first process takes place in all climatevegetation zones, however, with different intensity. The limestone dissolving mostly depends on the mineralization and humification intensity, i.e. on the quantity of produced $\mathrm{H}_{2} \mathrm{CO}_{3}$ and humic acids, as well as on the temperature, the amount of rainfalls, vegetation etc. This process of the limestone dissolving has consequences and effects on the genesis and properties of calcomelanosols.

The second very important process in their genesis is the accumulation of organic matter. The humification creates humus which is important for the soil properties. The mollic humus-accumulative horizon is reach in organic matter (humus), it has a dark color and much better thermal properties. The organo-mineral complexes, the humates and coprogenic humus formation of stable crumb structure and have a special effect on the water-air regime in the soil. At the same time, the accumulation of humus increases the absorption capacity of these soils.

The third process appears in the brownised calcomelanosols and calcocambisols that form the cambic horizon (B)rz, and it is marked as degradation, clay-forming process and brownization. Opinions for this process are given by Filipovski [8], as well as by Cirić and Pavićević $[9,10]$ who claim that the brownization process leads to dehumization and release of clay from the clay-humus complexes, without changing its mineralogical and chemical composition, and [10] points out that it is not clear whether clay decomposition is carried out in this process as well. In addition, Filipovski commented Spirovski [11] and Filipovski [12] who claim that chemical weathering through hydrolysis takes place in this process, at the same time forming clay (argillisation) and releasing iron oxides, and Laatsch [13] has determined that in this process, with the chemical weathering of the secondary minerals releases iron sesquioxides that give the soil brown and reddish-brown color. This brownization process occurs in conditions when the calcomelanosols form solum with depth from 30 to $40 \mathrm{~cm}$ even in conditions with fewer temperature variations. The intensity of the brownization process grows in the case of higher temperatures. New humus is no longer accumulated in the lower part of the solum at the brownised calcomelanosols and calcocambisols, which is located under the depth of the biological accumulation. When the solum will reach a depth of 30 to $40 \mathrm{~cm}$, the humidity in its lower part will become higher, the temperature will become more constant and the conditions for microbiological processes for humus mineralization will become more favorable. With the decreasing of the content of humus, the crumb aggregates decompose, the clay is released, the mass becomes more compacted, and nut, polyhedral structure. New quantities of clay can be obtained with the deepening of the (B)rz horizon and thus, (limestone dissolution- decarbonization) accompanied by a release of the clay silicate residium from it, a process that runs quite slowly.

According to [8], the brownisation starts from the bottom up, i.e. from the limestone up, and can take place in two phases whereby in the first phase only the color begins to change (the humus is lost), it becomes brown, while in the second phase, the other properties, especially physical properties of the soil begin to change (the structure is changed, i.e it becomes less loose, the non-capillary porosity decreases and the aeration and water permeability 
decreases). The chemical properties also change the content of humus and nutrients decreases, the acidity of the reaction increases, and the base saturation percentage decreases. This process can explain the increased content of clay in the horizon (B), which in these soils is marked as (B)rz, as it is formed with the release of the residuum from the limestone. In the first phases (B)rz is shallow, even shallower than in the Amo horizon at the subtype brownised calcomelanosols and in the later phases, it goes deeper and becomes more dominant, as in the calcocambisols, and becomes one of the diagnostic signs of this soil type.

Clay eluviation can occur in the genesis of the calcocambisols, a process characterized by soil subtype: Luvic. This process contributes for a larger textural differentiation of the horizons, and initial formation of the horizon E. Information on the genesis of calcomelanosols and calcocambisols can be found in the papers of [7, 14-29].

There are various opinions for the genesis of terra rossa. All of them refer to the origin of terra rossa and the relation between terra rossa and the parent material, whereby some of the opinions are even opposed. Most of the theories and opinions are presented by [8]. There is a so called residual theory regarding the genesis of terra rossa. It has been present for a longer time and it is a result of several years of studies carried out by some Croatian geologist Tućan and Marić cf. in [7] who studied the Croatian karst. This theory is accepted by some soil scientists [30]. According to this theory, terra rossa are mainly lithogenic soils as there are no significant differences between the residium and the mineral part of the soil. This opinion is also shared by the authors as they have been comparing the chemical and mineral composition of the residium and terra rossa. According to the residual theory, during the genesis of terra rossa, the residuum does not change significantly, which means that the terra rossa represents release residuum obtained from the limestone dissolution. This dissolution takes place in various climate conditions, which means that the Mediterranean climate is not a prerequisite for the formation of terra rossa. The genesis of terra rossa takes place in the presence of pure limestone, with a small content of residium, with red color and close ratio of $\mathrm{SiO}_{2}: \mathrm{R}_{2} \mathrm{O}_{3}$, whereby this residium originates from terra rossa which material was integrated in the limestones during the formation. In the later process of decarbonization, the residuum releases from the limestone and creates the mineral part of the soil. This process of releasing residuum is really slow, takes place for a long time with biochemical dissolution at various climate conditions.
According to the other theory cf. in [7], the silicate residium of the limestone is not identical to terra rossa. It is released with the dissolution of the limestone dissolves and as such, it represents a substrate which, with the rubification process, forms into terra rossa. The rubification process that took place in the past, but also takes place currently, especially in the Mediterranean and Subtropical areas, characterized with various pronounced characteristics, and especially dry and hot summers and dry and hot soil climate.

The processes that form terra rossa and some other ferralitic soils, Duchaufour, cf. by Filipovski [7] are called ferrallitisation, and the formation of terra rossa - rubification.

The author [31] has noted that in very warm and humid Mediterranean areas, such as Lebanon, the release of the residium and rubification occurs quickly and recent terra rossa is formed. Pavićević, [32] also considers that in the karst of the Adriatic Sea, where there are exceptionally high amounts of rainfall, the rubification is a modern process and that terra rossa is formed directly or with rubification of other soils. The same author divides terra rossa in the karst of the Adriatic coast into two groups: primary, formed with direct rubification of the residium and secondary, formed with rubification of other soil types.

Our research of the mineral composition of fractions (sand, silt) of the total soil, the geological substrate and the unsoluble remains in terra rossa, have indicated that the largest portion of minerals in the soil is the same as in unsoluble remains, but we must not disregard the fact that there is increased content of quartz in the sand fraction and the formation of vermiculite whose presence was not noted in the unsoluble remains [6].

\section{Evolution of the soils formed on limestones and dolomites}

The evolution of calcomelanosols has been studied by several authors in our country. Using the knowledge from our additional research from then until today, Filipovski, [8] has concluded that the evolution of calcomelanosols has taken place in three directions: a) forming of calcocambisols (organogenic $\rightarrow$ organomineral/haplic $\rightarrow$ brownized calcomelanosol); b) forming of terra rossa (organogenic $\rightarrow$ organomineral/haplic $\rightarrow$ rubified calcomelanosol); and c) forming of calcomelanosol with mor or tangel-humus (organogenic $\rightarrow$ organomineral/haplic $\rightarrow$ calcomelanosol with mor humus with organic $\mathrm{O}$ horizon). Whereby, the same author states that the evolution of the calcomelano- 
sols can stop in the initial phase and it can be permanent (for example, during the phase of organogenic calcomelanosol). With the evolution of calcomelanosols, there is growth in the percentage of coverage of the ground with soil, the depth of the profile is increased, and this reduces the effect of the limestone over the soil processes and properties. Also, the author continues to state, the evolution significantly changes the other soil properties: structure, water-air properties, humus contents, as well as the morphological properties of the profile. Evolution is also influenced by the depth of the profile, relief, climate-vegetation conditions, nature of the substrate, erosion etc.

The first, organogenic phase is formed as an initial phase (A-R) in conditions when the accumulation of humus, due to any reason (poor residium, extreme permeability of the substrate, unfavorable climate conditions) occurs more intensively that the dissolving of limestone and formation of clay. Organogenic calcomelanosols are characterized by a very shallow Amo horizon (around $10 \mathrm{~cm}$ ) which lies directly on top of the hard limestone and dolomite. They contain high amounts of humus, over $15 \%$ in our region. Due to the dry soil climate conditions, microbiological processes in organogenic calcomelanosols have a weak intensity, and humification mainly occurs under the influence of the fauna.

In the second organomineral/haplic phase, calcomelanosols reach their full maturity and maximal biological activity. The organomineral/haplic calcomelanosol has a deeper profile. The Amo horizon amounts to about $30 \mathrm{~cm}$, it contains less humus, has a crumby structure, and a well developed humus-clay complex. A limestone skeleton can be present in the humus horizon. The organomineral/haplic calcomelanosol is a more frequent subtype than the previous subtype and it dominates the zone of high-mountain pastures.

The third phase, when these is brownization of calcomelanosol occurs with deepening of the profile. The brownized calcomelanosol represents a transitional phase towards calcocambisols. It is formed from the previous subtype with the initial appearance of the cambic horizon (B)rz which has lower depth than the humus-accumulative Amo horizon. The increase of the clay content in this cambic (B)rz horizon is mostly residual clay, left after the dissolution of $\mathrm{CaCO}_{3}$.

Filipovski [8] has also described the evolution of calcomelanosols up to the formation of rubified/rhodic luvic calcomelanosols. Rubified/rhodic luvic calcomelanosols is a transitional phase leading to terra rossa. In this phase there is the initial formation of red cambic (B)rz horizon which has a smaller depth than the humus-accumulative horizon. In our conditions, it can be found in the lowest zones of Galichica, immediately next to Ohrid Lake, where the impact of the modified Mediterranean climate can be felt, with the respective vegetation and limestones with red residium.

Certain authors, such as $[15,33]$ describe the evolution of calcomelanosols towards cinnamonic forest soils/Chromic Luvisol on saprolite (WRB). In addition to calcomelanosols, terra rossa is mentioned as a previous stadium of calcocambisols.

In the case of calcocambisols, depending on the processes present in the soils, similar to the previous type, they can evolve into three directions: lesivation (illimerization), rubification, humusation and transformation into terra fusca.

In our region, illimerization is the most common case of evolution of calcocambisols, whereby there is the following evolution sequence: typical calcocambisol $\rightarrow$ illimerized/luvic calcocambisol. Illimerization according to [7] is usually present when the solum of these soils reaches a depth of around 50 to $60 \mathrm{~cm}$. Such is the case in level fields and in negative forms of the karst relief. In these relief forms, there is little surface running-off of water and it leaches the bases more intensively, there is weak acidification, as well as peptization and eluviation of clay. After this process reaches a certain level, under the A horizon there is an initial formation of the eluvial E horizon, and the clay is then transferred mechanically, without any changes to its chemical and mineral composition.

The rubification of calcocambisols has been described by [32, 34], cf. by Filipovski [7]. It is present in the lowest zone of the oak region, where these soils are present in complexes with terra rossa. The devastation of the forest and tillage on these soils contribute to the reduction of humus, for bigger heating and drying of the soil, which are key conditions for the hydrated sesquioxides to transform into nonhydrarted (hematite) which are red in color.

In addition, Ćirić [9] cf. by Filipovski [7] describes the third direction, humification of calcocambisols in the higher zones where these soils are present. This evolution occurs with the devastation of forests and the increase of surfaces with grass vegetation, where under its influence, after the erosion of the A horizon in the remainder of the solum ((B)rz horizon) the A horizon is formed again. These humificated calcocambisols do not differ from the brownized calcomelanosols.

The evolution of terra rossa researched by several authors: [12, 34, 35], by certain authors from the former Yugoslavian Republics: [29, 32, 37-39], 
as well as by others: [31, 40-43]. In all of the research by these authors, three directions of the evolution of terra rossa have been pointed out: 1 . Brownization, 2. Illimerization and 3. Progradation (humification).

Brownization, according to [7], is present in terra rossa which after the withdrawal of the Mediterranean climate, has remained in conditions with higher moisture and lower temperatures. This is even more intensified if the Mediterranean climate is additionally weakened or the environmental conditions change (forest, deeper solum, cooler and wetter expositions). With all of these processes, the top part of the solum is brownized, where under the influence of more humid and cooler conditions the rubification is incomplete and slow. The author has pointed out that there is a partial regression of rubification with the formation of more hydrated sesquioxides (goethite) and with the appearance of brown or more often red-brown color (brownized terra rossa).

Illimerization is present in climates that are even more humid, at higher altitudes, in negative forms of karst relief with stronger surface humidification and deeper solum. In this terra rossa the processes of acidification and peptization of colloids and their leaching are stronger. The author clarifies that these processes strengthen the texture differentiation with clear signs of leaching the clay from the $\mathrm{A}$ horizon into the $\mathrm{Bt}$ horizon and with the appearance of the initial formation of the E horizon (luvic terra rossa).

The third direction of evolution is progradation (humification) which consists of an accumulation of a higher quantity of humus into the already formed terra rossa (most often under the influence of grass vegetation). The dark humus horizon differs from the one in rhodic luvic calcomelanosols because it contains less humus and has a crumb structure (humic terra rossa) [7].

\section{Classification of the soils formed on limestones and dolomites}

The studied soils formed on limestone and dolomite have been classified according to the classification of Škorić, [24], Table 1.

Table 1. Classification of the soils formed on limestones and dolomites according to Škorić, [24]

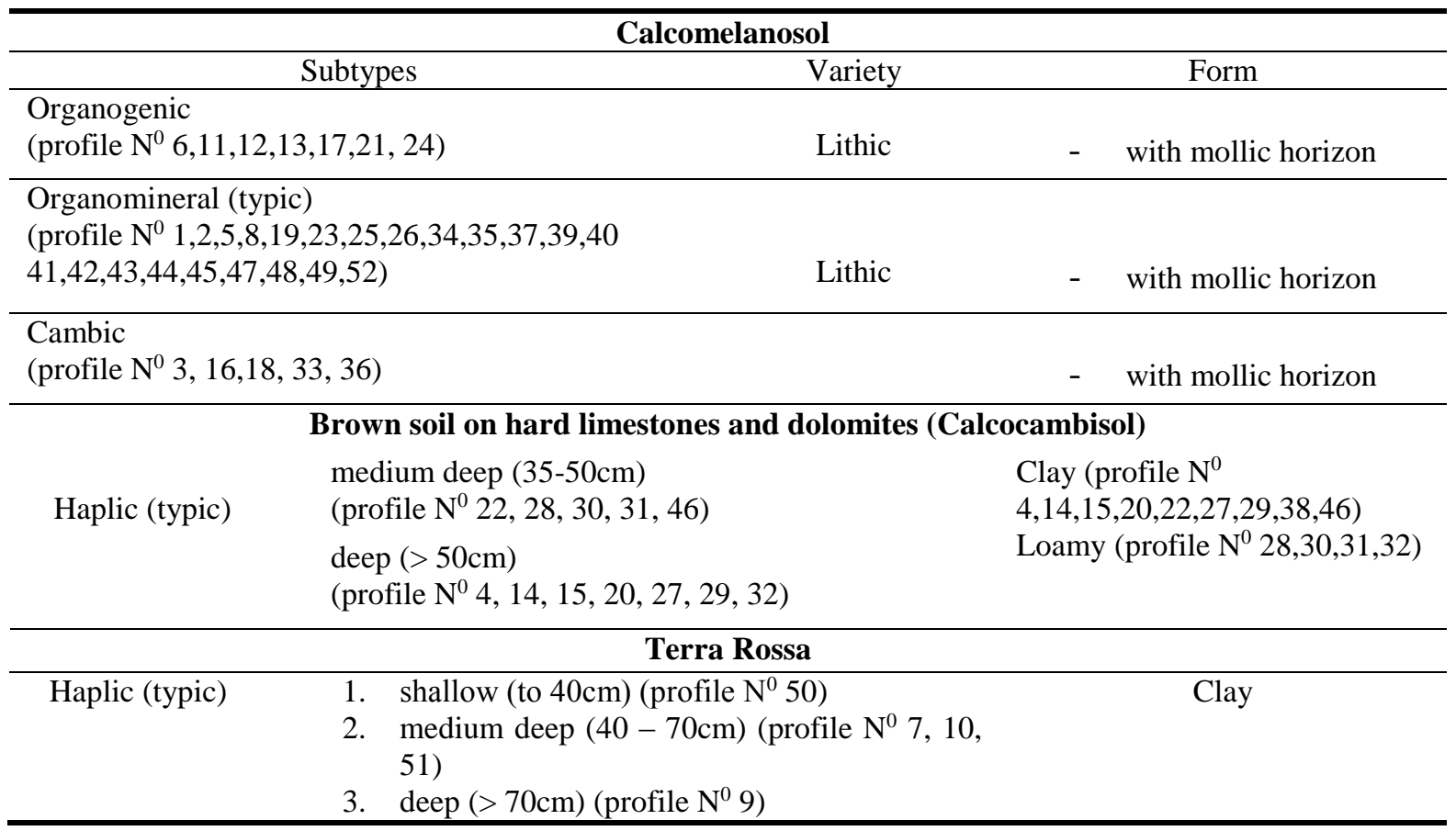

We have determined almost all types and subtypes of soils formed on limestone and dolomites: soil type - Calcomelanosol with subtypes: organogenic, organomineral (typic) and cambic, variety: lithic and form: with the mollic horizon. Calcocambisol, subtype Haplic (typic), variety: medium deep and deep and forms: clay and loamy. Soil type -
Terra Rossa, subtype Haplic (typic), variety: shallow, medium deep and deep and form: clay.

In calcomelanosols, the division into subtypes is based on the evolution principle. The division into varieties is based on the nature of the substrate, and the division into forms is based on the nature of the humus horizon. 
In calcocambisols and terra rossa, the division into subtypes is based on the evolution principle. In these two soil types, the division into varieties is based on the profile depth, and the division into forms is based on the mechanical composition.

According to WRB (World Reference Base for Soil Resources) [4], Calcomelanosol is classified as Rendzic Leptosol (lithic, molic), and according to the FAO Soil Classification, [41] it is designated as Rendzic Leptosol.

Brown soil on hard limestones and dolomites according to the WRB classification represents Chromic Leptic Luvisol on hard limestones (skeletic, humic), and according to the FAO Classification: Chromic Luvisol on hard limestones.

According to the World Reference Base for Soil Resources, Terra Rossa is classified as WRB Rhodic Leptic on hard limestones, and according to the FAO Classification it falls within Ferric Luvisol on hard limestones.

According to the proposed classification of Filipovski, [44], calcomelanosols fall within the major group of Molisols, while calcocambisols and terra rossa fall within the major group of Cambisols.

\section{CONCLUSION}

The key processes in whose genesis are: the dissolving of $\mathrm{CaCO}_{3}$ and $\mathrm{MgCO}_{3}$ from limestone and dolomite and their leaching; accumulation of organic matter and the formation of humus horizon and formation of horizon (B)rz (only in brownized calcomelanosols). The third process is the most specific in the genesis of calcocambisols and terra rossa.

The evolution of the soils formed on limestones and dolomites happens in three directions: calcomelanosol appears as a first phase and goes towards: the formation of calcocambisols (organogenic $\rightarrow$ organomineral $\rightarrow$ chromic luvic); the formation of terra rossa (organogenic $\rightarrow$ organomineral $\rightarrow$ rhodic luvic); and the formation of calcomelanosol with (mor) or tangel humus (organogenic $\rightarrow$ organomineral $\rightarrow$ calcomelanosol with mor humus with $\mathrm{O}$ organic horizon.

In our research, we have determined the following soil types and subtypes formed upon limestones and dolomites: soil type - Calcomelanosol with the subtypes: Organogenic, Organomineral/Haplic and Cambic, variety: lithic and form: with mollic horizon; Calcocambisol with subtype: Haplic (typic), variety: medium deep and deep and forms: clay and loamy and Terra Rossa with subtype: Haplic (typic), variety: shallow, medium deep and deep and form: clay.

\section{REFERENCES}

[1] Filipovski Gj. et.al: Priručnik za ispitivanje zemljišta. knj. IV; Metodika terenskog ispitivanja zemljišta. Jugoslovensko drustvo za proučavanje zemljišta, Beograd, 1967.

[2] J. Mitrikeski, T. Mitkova: Praktikum po pedologija. Zemjodelski fakultet, Skopje, 2006, pp. 1-164.

[3] Filipovski Gj: Pochvite na Republika Makedonija na topografska osnova 1:200 000, (Istochno od Grinich), Tolkovnik, Univerzitet "Sv. Kiril i Metodij”- Zemjodelski institut, Skopje, 2015, pp. $1-250$.

[4] WRB - World Reference Base for Soil Resources: Diagnostic Horizons, Properties and Materials. Chapter 3, World Reference Base for Soil Resources, FAO, ISSS-AISS-IBG, IRSIC, Rome, Ita1y, 2006, pp. 1-128.

[5] M. Markoski: Genesis and properties of soil formed upon limestones and dolomites in the Republic of Macedonia. Faculty of Agricultural Sciences and Food, Doctoral dissertation, Skopje, (2013), pp. 1163.

[6] M. Markoski, T. Mitkova, K. Vasilevski, Z. Tomić, M. Andreevski, V. Tanasković, S. Nečkovski: Natural conditions for the formation of the soils upon limestone and dolomite in the Republic of Macedonia, 02 Symposium Proceedings Vol II-URL.pdf, (2015), pp. 659-672.

[6a] M. Markoski, T. Mitkova, K. Vasilevski, Z. Tomic, M. Andreevski, V. Tanaskovic: Mechanical composition of the soils formed on limestones and dolomites in the Republic of Macedonia. Contributions, Sec. Nat. Math. Biotech. Sci., MASA, Vol. 36, $\mathrm{N}^{0} 1$, (2015), pp. 43-50.

[7] Gj. Filipovski: Soil of the Republic of Macedonia. Macedonian Academy of Sciences and Arts, Skopje, Vol III, 1997, pp. 130-213.

[8] Gj. Filipovski: Soil of the Republic of Macedonia. Macedonian Academy of Sciences and Arts, Skopje, Vol II, 1996, pp. (11-55), 1-296.

[9] M. Ćirić: Zemljišta planinskog područja Igman Bjelašnica. Radovi Šumarskog fakulteta i Instituta za šumarstvo u Sarajevo. Sarajevo, kn.10. sv.1, (1966).

[10] Pavićević, N: Planinske crnice - Buavice na crnogorskom kršu, doktorska disertacija. Univerzitet $u$ Beogradu, Poljoprivredni fakultet, Zemun, (1956).

[11] J. Spirovski: Pochvoobrazuvanje vrz varovnicite vo Demirhisarsko-Kichevskiot reon. Godishen zbornik na Zemjodelsko-shumarski fakultet, Zemjodelstvo, T, XV, Skopje, (1963), pp. 501-523.

[12] Gj. Filipovski: Pedologija. Chetvrto i preraboteno izdanie, Univerzitet Kiril i Metodij, Skopje, 1993, pp. $1-570$. 
[13] W. Laatsch: Dynamik der mitteleuropäischen Mineralböden. 4. Aufl. Th. Steinkopf, Dresden und Leipzig, 78 Abb. Kart. XI, 1957, pp. 1-280.

[14] D. Popovski, L. Manusheva: Pochvite na visokoplaninskite pasishta na Bistra. Godishen zbornik na Zemjodelsko-shumarski fakultet. Zemjodelstvo, T. XV, Skopje, (1962), pp. 285-317.

[15] J. Spirovski: Pochvite vrz varovnik pod chetirinari kaj Suva Gora. Godishen zbornik na Zemjodelskoshumarski fakultet. Zemjodelstvo. T. XX, Skopje, (1967), pp. 19-29.

[16] J. Spirovski: Pochvite pod chetirinari na Shar Planina (SRM). Godishen zbornik na Zemjodelskoshumarski fakultet. Kn. XXIII, Skopje, (1970), pp. 175-184.

[17] J. Spirovski: Pochvite pod visokoplaninskite pasishta na Suva Planina (SRM). Godishen zbornik na Zemjodelsko-shumarski fakultet. Kn. 25, Skopje, (1973).

[18] Gj. Tanev: Pochvite vo podrachjeto na Vodno, Kitka i Lisec. (sekcija Skopje-Titov Veles 1). Zbornik na Zemjodelski institut. Skopje, Kn. IV, (1969).

[19] Gj. Tanev: Prilog kon prouchuvanje na pochvite vo podrachjeto na Ljuboten i Zeden (sekcija Kachanik 4). Zbornik na Zemjodelski institut. Skopje, Kn. IV, (1972).

[20] Gj. Tanev: Pochvite vo podrachjeto na Jakupica, Babuna i Bisa (sekcija Skopje-Titov Veles 3). Zbornik na Zemjodelski institut. Skopje, Kn. VIII, (1972a)

[21] Lj. Micevski, K. Vasilevski, J. Acevski: Pedoloshki prouchuvanja na pochvite vo izvornoto podrachje na Patishka reka. Godishen zbornik na Shumarski fakultet, Kn. XXXIV, Скопје, (1991).

[22] L. Vilarov: Pochvite na Karaorman. Godishen zbornik na Zemjodelsko-shumarski fakultet, Kn. XIII, Skopje, (1960).

[23] D. Popovski, L. Vilarov, Gj. Tanev: Pochvite na del od povrshinite vo reonot na Gostivar, Kichevo, Krushevo i Ohrid. Zbornik na Zemjodelski institut. Kn. IV. Skopje, (1969), pp. 43-96.

[24] A. Škorić, Gj. Filipovski, M. Ćirić: Klasifikacija zemljišta Jugoslavije. Posebna izdanja. Akademija nauka i umetnosti Bosne i Hercegovine, Sarajevo, Knjiga LXXVIII, 1985.

[25] J. Mitrikeski, D. Petkovski: Geneza, fiziografija i klasifikacija na pochvite na Trojachkata kotlina. Nauchna tribina. Trojachka kotlina. Drushtvo za nauka i umetnost, Prilep, (1988), pp 39-77.

[26] A. Djordjević: Genesis, classification and properties of the soil of the limestone massif Rajca as the basis for their rational use. University of Belgrade. Faculty of Agriculture, Master Degree Thesis, (1993), pp. 1-127.
[27] D. Petkovski, Lj. Melovski: Content of total and available forms of heavy metals in calcocambisols and hromic cambisols in the region of Skopje. Zemljište i biljka. Beograd, vol. 55 o 3, (2006), pp. 221-234.

[28] B. Vrbek, B, I. Pilaš: Prilog poznavanju tala Štirovače na Velebitu. Rad - Šumar. inst. Jastrebar, 42 (2), (2007), pp. 155-166.

[29] R. Corić: Adsorpciske značajke crveničnih tala na karbonatnim sedimentima. Sveučilišta u Zagrebu, Agronomski fakultet Zagreb, 2009, pp. 1-126.

[30] M. Ćirić, D. Aleksandrović: Jedno gledište o genezi terra rossa (crvenice). Zbornik radov. Poljoprivredni fakultet, Beograd, (1959), pp. 1-12.

[31] M. Lamouroux: Étude de sols forms sur roches carbonates. Pédogenése fersalittique au Liban, ORSTOM, Paris, N ${ }^{\circ}$ 56, 1972, pp. 1-266.

[32] N. Pavićević: Crvenice Crne Gore i Hercegovine. Arhiv za poljoprivredne nauke, Beograd, br. 32, (1958).

[33] T. Nikolovski, J. Matvejeva, J. Stevchevski: Sindinamski razvitok na vegetacijata i pochvite na arealot na ass. Carpinetum orientalis typicum vrz tvrdi varovnici. Godishen zbornik na Zemjodelsko-shumarski fakultet, Shumarstvo, Kn. XXV, Скопје, (1973).

[34] N. Pavićević: Tipovi zemljišta na Suvoj Planini. Zemljišta i biljka, Beograd. god II. br.1. (1953), pp. $1-48$.

[35] D. Popovski: Geneza i svojstva na crvenicite vo NR. Makedonija. Godishen zbornik na Zemjodelsko-shumarski fakultet. Zemjodelstvo. T. XIII, Skiopj, (1960), pp.109-155.

[36] Gj. Filipovski, M. Ćirić: Zemljišta Jugoslavije. Posebna publikacija. JDPZ. Beograd. No 9, 1963, pp. 9-483.

[37] M. Gračanin: Pedologija, III dio. Sistematika tala. Školska knjiga, Zagreb, 1951, pp. 1-248.

[38] B. Pušić, M. Kurtagić: Tla Istre. Zemljište i biljka. Beograd. God. VIII. No 1-3, (1958).

[39] G. Durn, F. Ottner, F, D. Slovenec: Mineralogical and geochemical indicators of the polygenetic nature of terra rossa in Istria, Croatia. Geoderma. 91, (1999), pp. 125-150.

[40] Soil Survey Staff: Soil Taxonomy: A Basic System of Soil Classification for Making and Interpreting Soil Surveys. USDA Handbook, US Government Printing Office, Washington, DC, No 436, 1975.

[41] FAO - UNESKO: Soil map of the World. Revised legend, FAO, Rome, (1988).

[42] J. Foster, D. J. Chittleborough, K. Barovich: Gen esis of a terra rossa soil over marble and the influence of a neighbouring texture contrast soil at Delamere, South Australia. Supersoil 2004, Proceedings of the 3rd Australian New Zealand Soils Conference, University of Sydney, Australia, 5-9 
December 2004 (Singh, B., ed.), CDROM published by The Regional Institute Ltd., pp. 1-8.

[43] F. Jin - Liang, C. Zhi - Jiuc, Z. Li-Ping: Origin of terra rossa over dolomite on the Yunnan-Guizhou
Plateau, China. Geochemical Journal, Vol. 43 (2009), pp. 151-166.

[44] Gj. Filipovski: Soil Classification of the Republic of Macedonia. Macedonian Academy of Sciences and Arts, Skopje, 2006, pp. 1-337.

\title{
ГЕНЕЗА, ЕВОЛУЦИЈА И КЛАСИФИКАЦИЈА НА ПОЧВИТЕ ОБРАЗУВАНИ ВРЗ ВАРОВНИЦИ И ДОЛОМИТИ ВО РЕПУБЛИКА МАКЕДОНИЈА
}

\author{
Татјана Миткова, Миле Маркоски \\ Факултет за земјоделски науки и храна, Универзитет „Св. Кирил и Методиј “, \\ Скопје, Република Македонија
}

Испитувани се почвите образувани врз варовници и доломити на различни локации во Република Македонија. Овие почви по својата генеза и еволуција и по своите својства се разликуваат од почвите образувани врз другите супстрати и имаат редица специфичности, при што сите својства во најголема мера зависат од матичниот супстрат. Овие почви заземаат голем дел од почвениот покривач на Република Македонија. Теренските истражувања се извршени според општо прифатениот метод во нашата земја [1, 2]. Поголем дел од нив се под високопланински пасишта, некои парцели се под ливади и ниви. Тие имаат големо значење за побрзиот развој на шумарството, туризмот како и за развојот на земјоделството во ридскопланинските недоволно развиени подрачја во нашата земја.

Клучни зборови: почви образувани врз варовници и доломити, генеза, еволуција, класификација 